\title{
クモ膜下出血後の脳血管孪縮における noradrenergic
}

\section{system の関与一フサリン酸の効果一 \\ 1. 急性実験}

\author{
田中耕太郎
}

要旨 : [目的]クモ膜下出血後の脳血管孪縮に括けるノルアドレナリン (NA) 作動性神経因子の 関与の有無を検討した。〔万法〕16匹の成猫を用い，頭空法により脳軟膜血管を観察し，新鮮自 家血大槽内注入群と 4 日間 incubate した自家血・髄液等量混合液大槽内注入群にわけ実験的 脳血管挛縮を作製した。 これに対しドーパミンー $\beta$-水酸化酵素の特異的阻害剂であるフサリン酸 (FA) $(50 \mathrm{mg} / \mathrm{kg})$ 静注の効果を検討した. 〔結果〕（1）両群ともに FA 投与後，血圧下降とと もに脳軟膜動脈は拡張を示し, 投与後30分以降では有意な $(\mathrm{p}<0.001)$ 挛縮寛解を認め口径は正 常化した。（2）両側大脳半球皮質，一側小脳半球皮質で水素クリアランス法により測定した局 所脳血流量もほぼ上記動脈と同様の経過を示し, 低下していた血流量はFA 投与後著明に改善し た.〔結論】新鮮自家血および 4 日間 incubate した自家血・髄液等量混合液による脳血管孪縮に はNA 作動性神経因子, 特に NA 作動性神経終末ょりの noradrenaline の放出元進の関与が示唆 された。!

Key words: クモ膜下出血, 脳血管孪縮, 脳血流量, ドーパミン- $\beta$-水酸化酵素, ノルアド レナリン作動性神経

(脳卒中 $2: 269-279,1980$ )

クモ膜下出血（SAH）後に生ずる脳血管挛縮は, その 予後を著しく悪化させ臨床的に古くから重要な課題とな って来だ1).しかしその病態生理については種々の因 子, 即ち serotonin, prostaglandin, oxyhemoglobin, 自律 神経因子, 物理的因子, 器質的因子等様々のものが提唱 されて来ているが，未だ確証なく ${ }^{2)}$, その治療法も確定 されていない3.

脳血管には比較的古くからノルアドレナリン作動性神 経を含め自律神経線維の密なる分布が認められ4), 最近 脳血流の自動調節に重要な役割を果たしている事が明ら かとなって来だ). 一方, $\mathrm{SAH}$ 後に種々の点でノルア ドレナリン作動性神経系の活動六進が認められる事が臨 床的に注目されている(5)

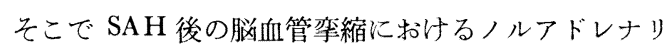

慶応義塾大学神経内科
ン作動性神経系の関与を調へ，かつその治療への応用の 可能性を検討する目的で，猫の実験的 SAH と打ける血 管挛縮に 対して, noradrenaline 合成酵素 dopamine- $\beta$ hydroxylase ${ }^{8)}$ の特異的阻害剂であるフサリン酸 (5-butylpicolinic acid) ${ }^{9)}$ を投与し，その効果を脳軟膜動脈口 径と局所脳血流量の二面より観察した。

本論文では大槽内に新鮮自家血または 4 日間 incubate した自家血・髄液等量混合液注入後の血管孪縮に対する 急性実験の成績を報告する。慢性実験については別に述 ベる予定である。

\section{方法}

成猫16匹を用い， $\alpha$-chloralose $(50 \mathrm{mg} / \mathrm{kg}$ ), urethane $(500 \mathrm{mg} / \mathrm{kg})$ 腹腔内投与により全身麻酔を行ない，1\% procaine hydrochloride に上る局所麻酔下に手術操作を 行なった。一側股動脈および股静脈にポリェチレン管を 
挿入乙, 股動脈チューブは王力変換器 (東洋測器 MPU05-290- III) 飞接続, 電気血正計 (日本光電 MP-3) を介 乙て多ペン記録器（理化電機 B-347）上K下行大動脈血 圧を連続記録した。股静脈チューブは薬刜注入に用い た。呼吸は気管切開後, alcuronium chloride $2 \sim 3 \mathrm{mg}$ 静 注により非動化した後, 人工呼吸器 (Harvard Model 662)により調節呼吸を行ない，実験中は呼吸を一定に 保った。

頭部を脳定位固定装置 (東大脳研型) に固定後, 左側 頭頂側頭部に直径 $15 \mathrm{~mm}$ の円形開頭を行ない，同部の 硬膜を切開してクモ膜を露出し，これを体温に温めた流 動パラフィンで覆った。な和実験中，猫の体温は電熱マ ットで $37^{\circ} \mathrm{CK}$ に保った。

脳軟膜血管の写真撮影をストロボ装置 (ニュンMS-2) を装着した顕微鏡写真撮影装置（ニコン PFM）により 行なった。接眼拉よび対物レンズは各々ニコン H.K. 5X，U 5Xを使用，フィルムは Kodak Panatomic-X を 用いた。撮影した写真を四つ切りに引伸し， $0.05 \mathrm{~mm}$ まで判読可能なノギスを用い，血管口径を計測した。こ の装置により四ら切り写真上の $1 \mathrm{~mm}$ は $15.0 \mu$ K相当す 万.

更に局所脳血流量測定には水素ガスクリアランス法を 用いた．右側前頭部，頭頂部和よび後頭部に歯科用ドリ ルにて直径 $2 \mathrm{~mm}$ の円形開頭を行ない, 硬膜切開後, 直 径 $250 \mu$ の白金電極（先端 $0.5 \mathrm{~mm}$ を除きポリウレタン にて絶緣されている) を右側前頭葉，頭頂葉，小脳半球 の皮質内に刺入した。また前述の左側開頭部において， 左側頭頂葉皮質内にも白金電極を刺入した，血流測定時 には $100 \%$ 水素ガスを気管カニューレ側ロより呼吸器か らの筀気と混合させて30秒間吸入させ, 吸入中止後 $\mathrm{i}$ 分 後よりのクリアランス曲線について initial slope 法 $^{10)}$ により局所脳血流量を算出した，実験終了後，脳を摘出 しホルマリンにて固定後, 電極の刺入部位を確認した。 な扣不関電極は後頭部皮下に装置した。

成猫16匹は 2 群にわけ，1 群は新鮮自家血注入群 (8 匹，平均体重 $2.9 \pm 0.9 \mathrm{~kg}$ ) で，新鮮自家動脈血 $0.5 \mathrm{cc}$ 大槽内に注入した. 他の 1 群は, 大槽内注入96時間前に 採取し， $37^{\circ} \mathrm{C}$ の定温度下で無菌的に incubate した0.5 cc 自家動脈血 - 髄液等量混合液大槽内注入群（8匹， 平均体重 $3.1 \pm 0.3 \mathrm{~kg}$ ) である。

各群において, 注入前, 注入直後, 注入後 5 分, 10 分, 20 分, 30 分, 40 分の各時期に脳軟膜血管写真撮影を 行ない, 注入後45〜 50分の時点で更に撮影を行なった
後, フサリン酸 $50 \mathrm{mg} / \mathrm{kg}$ をぬっくり静注，その直後， 5 分, 10 分, 20 分, 30 分, 40 分後の各洔点で同様に撮影 を行ない，脳軟膜血管口径の変化を経時的に钼察した。

局所脳血流量は，注入前，注入後10分，40分括よびフ サリン酸投与後10分，40分の時点で測定を行なった。

\section{結果}

I 、新解自家血注入㬰験

a) 脳軟膜動脈口径の変化

Fig. 1 亿脳軟膜血管写真の実際の典型例を示す. 左側 の写真は血液注入前に撮影したものであり，画面上左 上より右下に走るのが值径 $143 \mu$ の比较的太い動脈であ り，上方と下方にそれぞれ直径 $42 \mu ， 43 \mu$ の細い動脈を 分枝している. 中央の写真は注入後 5 分の時点のもので あり，脳表に血液が到達していない当拘らず，太い動

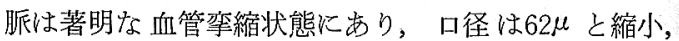
また細い動脈も各々， $23 \mu ， 27 \mu$ と著しく口径は縮小を 示した．右側の写真はフサリン酸投与後20分の時点のも ので平均動脈血圧 (MABP) の $68 \mathrm{mmHg}$ への下降とと もに, 動脈の血管孪縮は筧解し, 太い動脈の口径は $112 \mu$ と改善し, 細い動脈の口径もそれぞれ $36 \mu ， 38 \mu$ となり, フサリン酸の孪縮筧解効果が明らかである。

Fig. 2 および Table 1 は脳軟膜動脈の口径変化を注 入前の口径 $100 \mu$ 以上の比校的太い動脈（平均198.3土 $17.5 \mu$ ) と $100 \mu$ 未满の比較的細い動脈（平均60.5土6.6

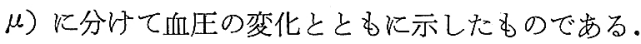

注入直後より血管孪縮が生じ，5分後に和いて最も著

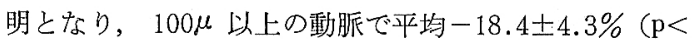

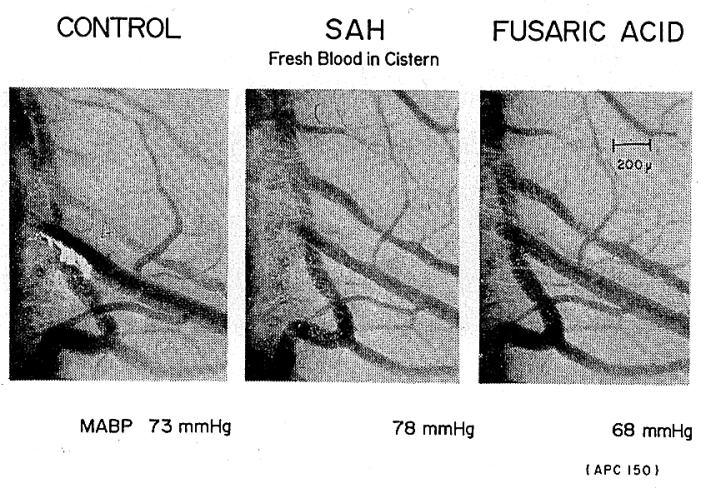

Fig. 1 Microphotographs of pial vessels of the cat. Left : control. Middle : 5 minutes after cisternal injection of $0.5 \mathrm{ml}$ of autogenous fresh arterial blood. Right : 20 minutes after intravenous administration of fusaric acid ( $50 \mathrm{mg} / \mathrm{kg}$ ). 
Table 1 Values of changes in pial arterial diameter and mean arterial blood pressure after cisternal injection of fresh blood, and the effect of fusaric acid

\begin{tabular}{|c|c|c|c|c|c|c|c|c|c|c|c|c|c|c|c|}
\hline \multirow{2}{*}{\multicolumn{2}{|c|}{$\begin{array}{l}\text { Initial diameter } \\
\qquad(\mu)\end{array}$}} & \multirow{2}{*}{ Time } & \multicolumn{6}{|c|}{ SAH (Fresh blood) } & \multicolumn{7}{|c|}{ Fusaric acid } \\
\hline & & & $\begin{array}{l}\text { Just } \\
\text { after }\end{array}$ & 5 & 10 & 20 & 30 & 40 & $\begin{array}{l}\text { Just } \\
\text { before }\end{array}$ & $\begin{array}{l}\text { Just } \\
\text { after }\end{array}$ & 5 & 10 & 20 & 30 & 40 \\
\hline \multicolumn{2}{|c|}{$\geqq 100 \mu$} & $\begin{array}{l}\% \text { Change in } \\
\text { diameter }(\%)\end{array}$ & & & & & & & & \multirow[b]{2}{*}{+0.8} & \multirow[b]{2}{*}{-0.9} & \multirow[b]{2}{*}{-4.9} & \multirow{2}{*}{$+\quad \begin{array}{r}* * * \\
\end{array}$} & \multirow[b]{2}{*}{$\begin{array}{r}* * * \\
+\quad 8.7\end{array}$} & \multirow[b]{2}{*}{+13.7} \\
\hline $\mathrm{m}$ & 198.3 & $\mathrm{~m}$ & -8.8 & -18.4 & -15.7 & -14.8 & -9.4 & -15.5 & -10.7 & & & & & & \\
\hline $\mathrm{SE}$ & 17.5 & SE & 1.5 & 4.3 & 3.8 & 3.4 & 3.3 & 3.4 & 2.8 & 9.6 & 10.3 & 5.5 & 3.6 & 5.0 & 2.9 \\
\hline $\mathrm{n}$ & 8 & $\mathrm{n}$ & 8 & 8 & 8 & 8 & 8 & 5 & 8 & 8 & 7 & 7 & 8 & 7 & 7 \\
\hline \multicolumn{2}{|c|}{$<100 \mu$} & $\begin{array}{l}\% \text { Change in } \\
\text { diameter }(\%)\end{array}$ & & & & & & \multirow[b]{2}{*}{-10.2} & & \multirow[b]{2}{*}{+10.7} & \multirow[b]{2}{*}{$+4.8 *$} & \multirow[b]{2}{*}{+5.2} & \multirow[b]{2}{*}{+7.2} & \multirow[b]{2}{*}{+18.1} & \multirow[b]{2}{*}{+21.3} \\
\hline $\mathrm{m}$ & 60.5 & $\mathrm{~m}$ & -13.3 & -18.0 & -14.8 & -11.5 & -5.7 & & $-10.1^{\dagger}$ & & & & & & \\
\hline $\mathrm{SE}$ & 6.6 & SE & 3.0 & 2.9 & 2.3 & 3.3 & 3.1 & 6.8 & 4.4 & 5.9 & 6.7 & 6.4 & 6.3 & 5.1 & 2.3 \\
\hline $\mathrm{n}$ & 8 & $\mathrm{n}$ & 8 & 8 & 8 & 8 & 8 & 5 & 8 & 8 & 7 & 7 & 8 & 7 & 7 \\
\hline \multicolumn{2}{|c|}{$\begin{array}{r}\text { Initial } \begin{array}{r}\mathrm{MABP} \\
(\mathrm{mmHg})\end{array}\end{array}$} & $\underset{(\mathrm{mmHg})}{\Delta \mathrm{MABP}}$ & & & & & \multirow[b]{2}{*}{+0.5} & \multirow[b]{2}{*}{-3.6} & \multirow[b]{2}{*}{+1.0} & \multirow{2}{*}{-29.0} & \multirow{2}{*}{$-12.7^{*}$} & \multirow[b]{2}{*}{-8.9} & \multirow[b]{2}{*}{-5.9} & \multirow[b]{2}{*}{$13.1^{\dagger}$} & \multirow{2}{*}{$-14 .^{\dagger}$} \\
\hline $\mathrm{m}$ & 91.6 & $\mathrm{~m}$ & -2.9 & -2.1 & -0.4 & -2.4 & & & & & & & & & \\
\hline SE & 9.3 & $\mathrm{SE}$ & 4.0 & 3.2 & 3.1 & 3.3 & 3.4 & 4.1 & 3.7 & 7.5 & 7.4 & 6.0 & 6.1 & 7.7 & 9.2 \\
\hline $\mathrm{n}$ & 8 & $\mathrm{n}$ & 8 & 8 & 8 & 8 & 8 & 5 & 8 & 8 & 7 & 7 & 8 & 7 & 7 \\
\hline
\end{tabular}

$\mathrm{m}$ : mean $\mathrm{SE}$ : standard error $\mathrm{n}:$ number of cases

${ }^{* * *} \mathrm{P}<0.001{ }^{* *} \mathrm{P}<0.005{ }^{*} \mathrm{P}<0.01 \quad+\mathrm{P}<0.05$

(フサリン酸投与後はフサリン酸投与直前值との比較である)

$0.001), 100 \mu$ 未渾の 動脈で平均 $-18.0 \pm 2.9 \%(\mathrm{p}<$ $0.001 ） の$ 有意な口径縮小が認められた。なおその際の $\mathrm{MABP}$ の変化は $\mathrm{SAH}$ 前に比べ平均 $-2.1 \pm 3.2 \mathrm{mmHg}$ であり, 有意でなかった。その後の挛縮はやや回復傾向 を示したが，太い動脈では回復が悪く，より明らかな孪 縮状態が持続した。

フサリン酸投与直前, $100 \mu$ 以上の動脈は注入前に比 べ, $-10.7 \pm 2.8 \%(\mathrm{p}<0.005), 100 \mu$ 末満の細い動脈 は $-10.1 \pm 4.4 \%(\mathrm{p}<0.05)$ の孪縮を示していた. 血圧 は+1.0土3.7mmHg で注入前の值と有意な変化は示し ていなかった、フサリン酸を投与すると，その直後より 血管孪縮は著しく寛解し, 太小動脈の口径は注入前值に

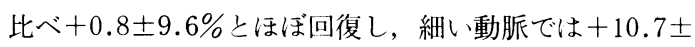
$5.9 \%$ 前值よりも口径大となった。即ち細い動脈で孪 縮寛解がより著明で，フサリン酸投与前值と比較し0.1 \%以下の危険率で有意な抆張であった。なお MABP は $-29.0 \pm 7.5 \mathrm{mmHg}$ の著しい低下を示した $(\mathrm{p}<0.001)$. その後 5 分, 10分までは低下した血压の回復傾向ととも に孪縮寛解効果は一時やや減弱する傾向を示した．しか し20分以降, 血圧が再たび徐々に低下する傾向を示すと ともに, 動脈は更に搪張を示し始め, 太い動脈と細い動 脈はともにそれぞれフサリン酸投与前值と比較し有意な
拡張 $(p<0.001)$ をみせた。 即ちそれぞれ30分後で+ $8.7 \pm 5.0 \% ， \pm 18.1 \pm 5.1 \% ， 40$ 分後で+13.7士2.9\%， $+21.3 \pm 2.3 \%$ であり注入前值をも上回る口径桩大を認 めた。血星はそれに対し鏡像的に，フサリン酸投与後30 分の時点で $-13.1 \pm 7.7 \mathrm{mmHg}(\mathrm{p}<0.05), 40$ 分の時点 で $-14.8 \pm 9.2 \mathrm{mmHg}(\mathrm{p}<0.05)$ と緩徐な低下傾向が持 続した。なおフサリン酸投与後細い動脈の方が太い動脈 に比べ拆張がより強い傾向にあったが，両者の差は推計 学的に有意ではなかった。

b) 局所脳血流量の変化

局所脳血流量の変化を部位別に Fig. 3 と Table 2 に 示寸. 各部位ともに注入前には平均 $44.9 \sim 52.5 \mathrm{ml} / 100 \mathrm{~g} /$ min の血流量であったが, 新鮮血注入後10分の時点で 平均-15.9 - $31.6 \%$ の有意な血流量減少を示した（p $<0.05 \sim p<0.005)$. その後注入後40分の時点では，各部 位ともに血流量はやや回復傾向をみせたが，依然一10.5 〜 $-24.8 \%$ の減少を示した. 注入後の脳血流減少度は各 部位間に当初より有意差なく，早期より脳全体にわた り diffuse な血流減少が明らかであった。

フサリン酸投与後10分において, 各部位ともに著明に 脳血流量は増加し, 注入前话と比較して+25.4〜+39.9 $\%$ の血流量増加が 観察され, 注入後 40 分の時点と比較 


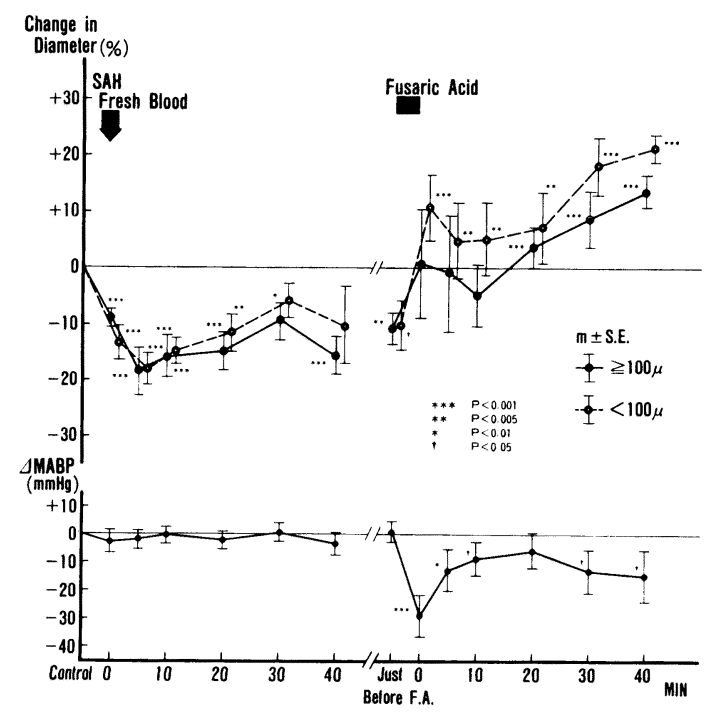

Fig. 2 Changes in pial arterial diameter and mean arterial blood pressure after cisternal injection of fresh blood, and the effect of fusaric acid.

し，それぞれ0.1〜 5\%以下の危険率の範囲で推計学的に 有意な増加であった。フサリン酸投与後40分の測定にお いても，10分の際に比べ血流量はやや少なくなって来て いるが，注入前に比べ平均 $+15.6 〜+32.9 \%$ 血流量増 加が持続していた.

II . 自家血・髄液等量混合液 $\left(4\right.$ 日間 $37^{\circ} \mathrm{C}$ にて incubate）注入実験

a) 脳軟膜動脈口径の変化

Fig. 4 に本群の実際の脳軟膜血管写真の一・例を示す. 左側の写真は注入前のもので, 画面上左上より右下へ走 る口径 $102 \mu$ の動脈とそれより右側に分岐する口径 $38 \mu$ の動脈が認められる.これらの動脈は注入後10分の時点 では中央の写真の如く，それぞれ口径 $57 \mu ， 21 \mu$ となり 一部に血管口径不同も伴なら著明な血管孪縮を示した。 右側の写真はフサリン酸投与後 20 分のものであるが，太 い動脈，細い動脈ともに口径は $84 \mu ， 26 \mu$ となっており 血管孪縮の著明な寛解を示している.

Fig. 5 および Table 3 はこれら脳軟膜動脈口径の変 化を注入前の口径 $100 \mu$ 以上 (平均 $229.0 \pm 18.2 \mu$ ) と 100 $\mu$ 未満 (平均66.5土8.3 3 ) の 2 群に分けてまとめたも のである.なおこれら 2 群の注入前の動脈口径と新鮮血 注入群のそれとの間には推計学的に有意差は認めなかっ た.

太い動脈および細い動脈ともに自家血・髄液等量混合

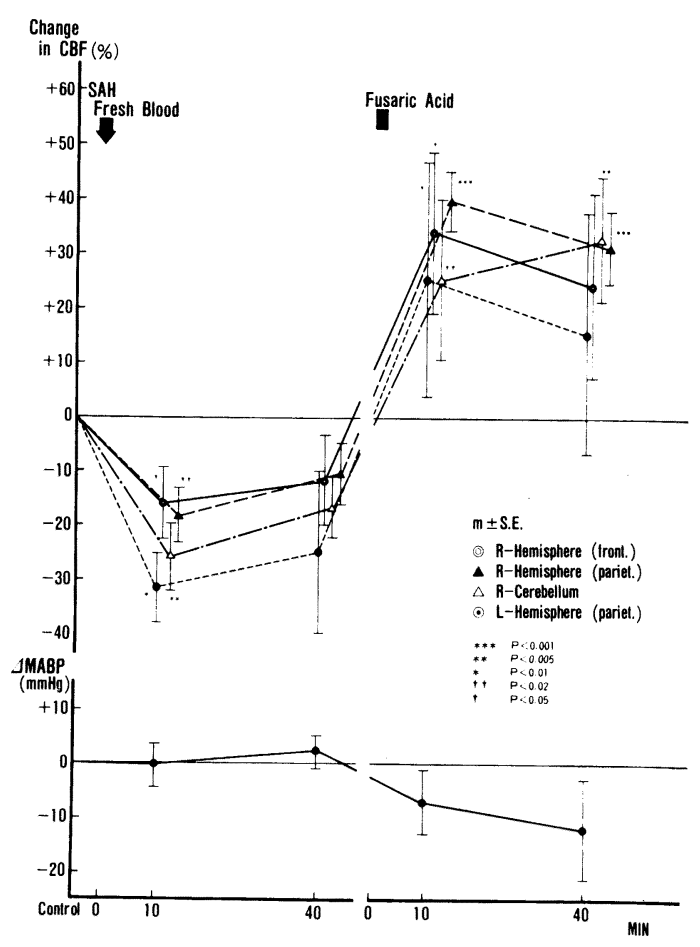

Fig. 3 Changes in regional cerebral blood flow in four regions after cisternal injection of fresh blood, and the effect of fusaric acid.

液注入後，まだ脳表に混合液が到達していない時点より 挛縮が認められ, 新鮮血注入群と同様, 5 分後で最も孪 縮は著明となり，それぞれー24.6土2.1\% $(\mathrm{p}<0.001)$ $-22.6 \pm 3.7 \%(\mathrm{p}<0.001)$ の口径変化を認めた. その後 も Fig. 5 に示す如く, ほぼ同程度の孪縮が持続し, こ れらの変化は新鮮血注入群よりも著明であった.

フサリン酸投与直前, 太い動脈は $-22.7 \pm 2.5 \%(\mathrm{p}<$ $0.001)$, 細い動脈も $-20.3 \pm 6.1 \%(\mathrm{p}<0.02)$ の血管孪 縮を認めたが，フサリン酸投与直後より血圧はー28.4土 $7.6 \mathrm{mmHg}$ の下降 $(\mathrm{p}<0.001)$ を示すとともに, 口径は 拡張傾向を示し，5分後ではそれぞれー6.0土4.3\%，一 $5.7 \pm 4.9 \%$ まで孪縮は改善し, フサリン酸投与直前と比 較すると太い動脈の拡張は危険率 $0.5 \%$ 以下で有意であ った.その後孪縮寛解の進展は一時やや緩徐となった が, フサリン酸投与後30分以降, 一時回復した血圧が再 度緩徐に低下傾向を示すとともに, 脳軟膜動脈も再たび 拡張を示し始めた。フサリン酸投与後40分の時点で太い

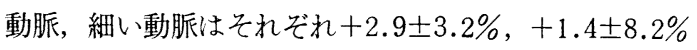
注入前を上回る口径を示し，フサリン酸投与直前值と比 
Table 2 Values of changes in regional cerebral 4 blood flow in four regions and mean arterial blood pressure after cisternal injection of fresh blood, and the effect of fusaric acid

\begin{tabular}{|c|c|c|c|c|c|c|c|}
\hline \multirow{2}{*}{ Site } & \multirow{2}{*}{\multicolumn{2}{|c|}{$\begin{array}{c}\text { Initial CBF } \\
(\mathrm{m} / / 100 \mathrm{~g} / \mathrm{min})\end{array}$}} & \multirow{2}{*}{ Time (min.) } & \multicolumn{2}{|c|}{ SAH (Fresh blood) } & \multicolumn{2}{|c|}{ Fusaric acid } \\
\hline & & & & 10 & 40 & 10 & 40 \\
\hline $\begin{array}{l}\text { R-Hemisphere } \\
\text { (front.) }\end{array}$ & $\begin{array}{l}\mathrm{m} \\
\mathrm{SE} \\
\mathrm{n}\end{array}$ & $\begin{array}{c}44.9 \\
2.8 \\
8 \\
\end{array}$ & $\begin{array}{l}\% \text { Change in } \mathrm{CBF}(\%) \\
\mathrm{m} \\
\mathrm{SE} \\
\mathrm{n}\end{array}$ & $\begin{array}{c}-15.9 \dagger \\
6.7 \\
8\end{array}$ & $\begin{array}{c}-11.7 \\
8.3 \\
7\end{array}$ & $\begin{array}{c}+34.1^{\dagger} \\
14.8 \\
8\end{array}$ & $\begin{array}{c}+24.3 \\
16.9 \\
8\end{array}$ \\
\hline $\begin{array}{l}\text { R-Hemisphere } \\
\text { (pariet.) }\end{array}$ & $\begin{array}{l}\mathrm{m} \\
\mathrm{SE} \\
\mathrm{n}\end{array}$ & $\begin{array}{c}52.5 \\
6.2 \\
7\end{array}$ & $\begin{array}{l}\% \text { Change in } \mathrm{CBF}(\%) \\
\mathrm{m} \\
\mathrm{SE} \\
\mathrm{n}\end{array}$ & $\begin{array}{c}-18.2 \dagger+ \\
5.1 \\
7\end{array}$ & $\begin{array}{r}-10.5 \\
5.8 \\
7\end{array}$ & $\begin{array}{c}+39.9^{* * *} \\
5.5 \\
7\end{array}$ & $\begin{array}{c}+31.5^{* * *} \\
6.7 \\
6\end{array}$ \\
\hline R-Cerebellum & $\begin{array}{l}\mathrm{m} \\
\mathrm{SE} \\
\mathrm{n}\end{array}$ & $\begin{array}{c}49.6 \\
6.0 \\
8\end{array}$ & $\begin{array}{l}\% \text { Change in } \mathrm{CBF}(\%) \\
\mathrm{m} \\
\mathrm{SE} \\
\mathrm{n}\end{array}$ & $\begin{array}{c}-25.9^{* *} \\
6.2 \\
8\end{array}$ & $\begin{array}{c}-16.7 t \\
5.7 \\
8\end{array}$ & $\begin{array}{c}+25.4{ }^{t \dagger} \\
14.8 \\
8\end{array}$ & $\begin{array}{c}+32.9^{* *} \\
11.4 \\
8\end{array}$ \\
\hline $\begin{array}{l}\text { L-Hemisphere } \\
\text { (pariet.) }\end{array}$ & $\begin{array}{l}\mathrm{m} \\
\mathrm{SE} \\
\mathrm{n}\end{array}$ & $\begin{array}{c}48.3 \\
4.1 \\
5\end{array}$ & $\begin{array}{l}\% \text { Change in } \mathrm{CBF}(\%) \\
\mathrm{m} \\
\mathrm{SE} \\
\mathrm{n}\end{array}$ & $\begin{array}{c}-31.6^{*} \\
6.4 \\
5\end{array}$ & $\begin{array}{c}-24.8 \\
14.9 \\
5\end{array}$ & $\begin{array}{c}+25.5 t \\
21.6 \\
5\end{array}$ & $\begin{array}{c}+15.6 t \\
22.2 \\
5\end{array}$ \\
\hline $\begin{array}{l}\text { Initial MA } \\
\qquad \begin{array}{l}\mathrm{m} \\
\mathrm{SE} \\
\mathrm{n}\end{array}\end{array}$ & $\begin{array}{l}\mathrm{P}(\mathrm{mn} \\
89.0 \\
7.5 \\
8\end{array}$ & & $\begin{array}{c}\triangle \mathrm{MABP} \\
(\mathrm{mmHg}) \\
\mathrm{m} \\
\mathrm{SE} \\
\mathrm{n}\end{array}$ & $\begin{array}{c}-0.4 \\
4.1 \\
8\end{array}$ & $\begin{array}{c}+2.2 \\
3.1 \\
8\end{array}$ & $\begin{array}{c}-7.0 \\
5.9 \\
8\end{array}$ & $\begin{array}{c}-11.9 \\
9.2 \\
8\end{array}$ \\
\hline
\end{tabular}

$\mathrm{m}$ : mean SE : standard error $\mathrm{n}$ : number of cases

${ }^{* * *} \mathrm{P}<0.001 \quad{ }^{* *} \mathrm{P}<0.005 \quad{ }^{*} \mathrm{P}<0.01 \quad$ †† $\mathrm{P}<0.02 \quad \dagger \mathrm{P}<0.05$

(フサリン酸投与後は SAH 後40分值との比較である)

Table 3 Values of changes in pial arterial diameter and mean arterial blood pressure after cisternal injection of incubated blood-CSF mixture, and the effect of fusaric acid

\begin{tabular}{|c|c|c|c|c|c|c|c|c|c|c|c|c|c|c|c|}
\hline \multirow{2}{*}{\multicolumn{2}{|c|}{$\begin{array}{l}\text { Initial diameter } \\
\qquad(\mu)\end{array}$}} & \multirow{2}{*}{ Time } & \multicolumn{6}{|c|}{ SAH (Incubated blood) } & \multicolumn{7}{|c|}{ Fusaric acid } \\
\hline & & & $\begin{array}{l}\text { Just } \\
\text { after }\end{array}$ & 5 & 10 & 20 & 30 & 40 & $\begin{array}{c}\text { Just } \\
\text { before }\end{array}$ & $\begin{array}{l}\text { Just } \\
\text { after }\end{array}$ & 5 & 10 & 20 & 30 & 40 \\
\hline \multicolumn{2}{|c|}{$\geqq 100 \mu$} & $\begin{array}{l}\% \text { Change in } \\
\text { diameter }(\%)\end{array}$ & & & & & & & & & & & & & \multirow{4}{*}{$\begin{array}{r}{ }^{\text {b }}+{ }^{* * *} \\
2.9 \\
3.2 \\
7\end{array}$} \\
\hline & 229.0 & $\mathrm{~m}$ & -13.2 & -24.6 & -23.5 & -21.1 & -19.6 & -21.9 & -22.7 & -7.5 & -6.0 & -6.8 & -4.4 & -2.5 & \\
\hline $\mathrm{SE}$ & 18.2 & $\mathrm{SE}$ & 2.8 & 2.1 & 3.4 & 3.0 & 2.7 & 3.2 & 2.5 & 5.9 & 4.3 & 3.1 & 1.9 & 3.3 & \\
\hline $\mathrm{n}$ & 8 & $\mathrm{n}$ & 8 & 8 & 8 & 8 & 7 & 6 & 8 & 8 & 8 & 8 & 8 & 6 & \\
\hline \multicolumn{2}{|c|}{$<100 \mu$} & $\begin{array}{l}\% \text { Change in } \\
\text { diameter }(\%)\end{array}$ & & & & & & & & & & & & & \multirow{4}{*}{$\begin{array}{r}\stackrel{\mathrm{a}}{\dagger} \\
+\quad 1.4 \\
8.2 \\
7\end{array}$} \\
\hline $\mathrm{m}$ & 66.5 & $\mathrm{~m}$ & -12.3 & -22.6 & -22.4 & -23.0 & -19.3 & -20.0 & -20.3 & -7.7 & -5.7 & -9.4 & -9.1 & -2.6 & \\
\hline SE & 8.3 & SE & 3.6 & 3.7 & 3.7 & 4.1 & 4.3 & 5.0 & 6.1 & 5.2 & 4.9 & 5.8 & 7.1 & 8.1 & \\
\hline $\mathrm{n}$ & 8 & $\mathrm{n}$ & 8 & 8 & 8 & 8 & 7 & 6 & 8 & 8 & 8 & 8 & 8 & 6 & \\
\hline Initial & $\begin{array}{l}\text { MABP } \\
(\mathrm{mmHg})\end{array}$ & $\underset{(\mathrm{mmHg})}{\Delta \mathrm{MABP}}$ & & & & & & & & & & & & & \\
\hline $\mathrm{m}$ & 90.9 & $\mathrm{~m}$ & +5.3 & +4.6 & +7.0 & +1.8 & +1.9 & +2.7 & 0 & -28.4 & -13.8 & -11.4 & -6.8 & -6.8 & -10.4 \\
\hline $\mathrm{SE}$ & 11.3 & $\mathrm{SE}$ & 2.5 & 2.6 & 4.8 & 3.1 & 4.0 & 4.2 & 4.8 & 7.6 & 10.0 & 8.5 & 6.9 & 10.0 & 14.8 \\
\hline $\mathrm{n}$ & 8 & $\mathrm{n}$ & 8 & 8 & 8 & 8 & 7 & 6 & 8 & 8 & 8 & 8 & 8 & 6 & 7 \\
\hline
\end{tabular}

$\mathrm{m}$ : mean $\mathrm{SE}$ : standerd error $\mathrm{n}$ : number of cases

*** $\mathrm{P}<0.001{ }^{* *} \mathrm{P}<0.005 * \mathrm{P}<0.01 \quad \dagger+\mathrm{P}<0.02 \quad \dagger \mathrm{P}<0.05$

(フサリン酸投与後はフサリン酸投与直前値との比較である)

新鮮血注入群との比較 ${ }^{\mathrm{a}}: \mathrm{P}<0.01 \quad \mathrm{~b}: \mathrm{P}<0.05$ 
CONTROL

SAH

FUSARIC ACID (Incubated Blood)

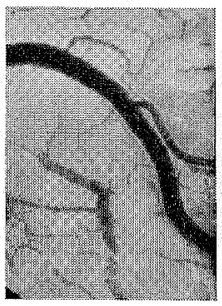

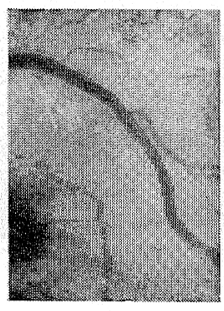

$121 \mathrm{mmHg}$

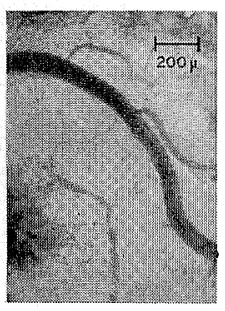

$98 \mathrm{mmHg}$
MABP $103 \mathrm{mmHg}$

CISTERNAL INJECTHON

(APC 153)

Fig. 4 Microphotographs of pial vessels of the cat. Left : control. Middle : 10 minutes after cisternal injection of $0.5 \mathrm{ml}$ of autogenous bloodCSF mixture incubated for 4 days. Right : 20 minutes after intravenous administration of fusaric acid $(50 \mathrm{mg} / \mathrm{kg})$.

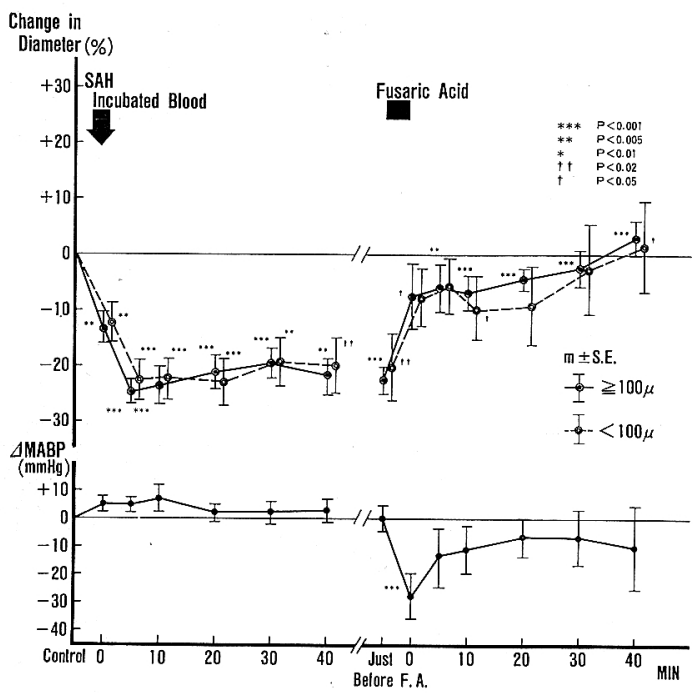

Fig. 5 Changes in pial arterial diameter and mean arterial blood pressure after cisternal injection of incubated blood-CSF mixture, and the effect of fusaric acid.

較して各々危険率0.1\%和よび $5 \%$ 以下の有意な拡張を 示した。

新鮮血注入群と比較すると，フサリン酸投与直前に括 いて太い動脈，細い動脈ともに本群の方が孪縮がやや強 い傾向にあった。フサリン酸の効果は，両群間に血圧変
化に差はなかったが，新㙰血注入群に比べ本群の方が弱 い傾向にあり，特に Table 3に示す如く30分以降でその 差は明らかであった。

b) 局所脳血流量の変化

各部位別の 局所脳血流量の 恋化を Fig. 6 と Table 4 に示す. 各部位ともに Table 4k示す如く，注入前は平 均 $43.3 \sim 57.6 \mathrm{~m} l / 100 \mathrm{~g} / \mathrm{min}$ の血流量を示し, 新鮮血注入 群との間で有意差は認めなかった。

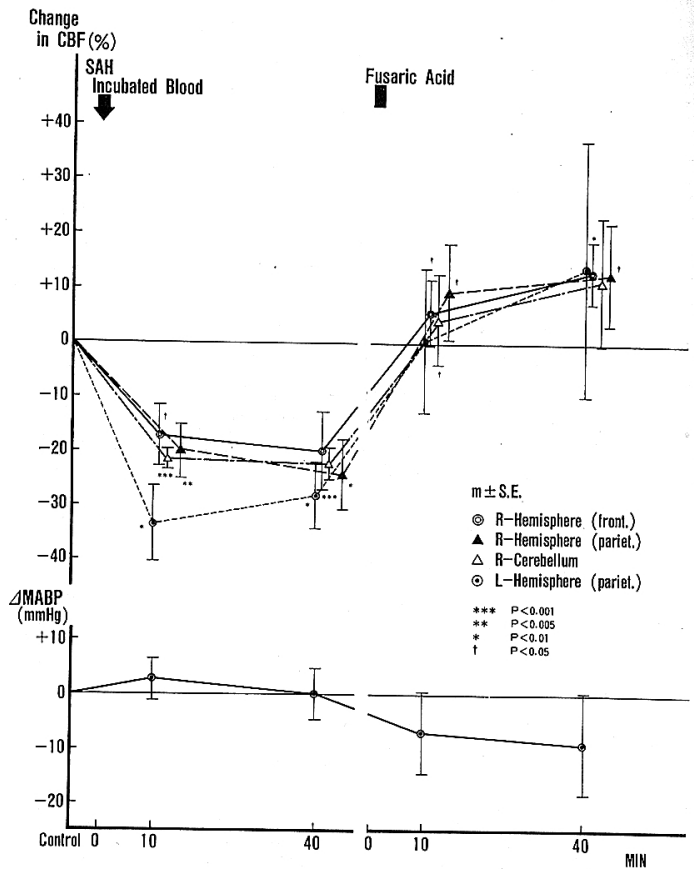

Fig. 6 Changes in regional cerebral blood flow in four regions after cisternal injection of incubated blood-CSF mixture, and the effect of fusaric acid.

自家血・髄液等量混合液注入後 10 分の時点で各部位と もに有意な $(p<0.005 \sim p<0.05)$ 血流量の低下を認め た.この状態は注入後 40 分の時点でもほぼ同程度に持続 し, 新㷛血注入群に比べ血流量低下は本群の方がやや強 い傾向にあった。

フサリン酸静注後10分の測定では各部位ともに著しい 血流量の回復を認め，それぞれ注入前値を若干上回る十 0.4〜+9.5\%の值を示した. 静注後40分でばその血流量 増加は更に軽度進展する傾向が認められた。このフサ リン酸投与後の血流量増加度は, 新焦血注入群と比較す ると，いずれの部位において子投与後10分，40分の測定 で少ない傾向にあった。 
Table 4 Values of changes in regional cerebral blood flow in four regions and mean arterial blood pressure after cisternal injection of incubated blood-CSF mixture, and the effect of fusaric acid

\begin{tabular}{|c|c|c|c|c|c|c|c|}
\hline \multirow{2}{*}{ Site } & \multirow{2}{*}{\multicolumn{2}{|c|}{$\begin{array}{c}\text { Initial CBF } \\
(\mathrm{m} l / 100 \mathrm{~g} / \mathrm{min})\end{array}$}} & \multirow{2}{*}{ Time (min.) } & \multicolumn{2}{|c|}{ SAH (Incubated blood) } & \multicolumn{2}{|c|}{ Fusaric acid } \\
\hline & & & & 10 & 40 & 10 & 40 \\
\hline $\begin{array}{l}\text { R-Hemisphere } \\
\text { (front.) }\end{array}$ & $\begin{array}{l}\mathrm{m} \\
\mathrm{SE} \\
\mathrm{n}\end{array}$ & $\begin{array}{c}51.5 \\
13.6 \\
6\end{array}$ & $\begin{array}{c}\% \text { Change in } \mathrm{CBF}(\%) \\
\mathrm{m} \\
\mathrm{SE} \\
\mathrm{n}\end{array}$ & $\begin{array}{c}-17.1^{\dagger} \\
5.6 \\
6\end{array}$ & $\begin{array}{c}-19.9 \\
7.2 \\
5\end{array}$ & $\begin{array}{c}+5.6^{\dagger} \\
6.0 \\
6\end{array}$ & $\begin{array}{c}+13.1^{*} \\
\quad 5.7 \\
\quad 6\end{array}$ \\
\hline $\begin{array}{l}\text { R-Hemisphere } \\
\text { (pariet.) }\end{array}$ & $\begin{array}{l}\mathrm{m} \\
\mathrm{SE} \\
\mathrm{n}\end{array}$ & $\begin{array}{c}43.3 \\
8.5 \\
8\end{array}$ & $\begin{array}{c}\% \text { Change in } \mathrm{CBF}(\%) \\
\mathrm{m} \\
\mathrm{SE} \\
\mathrm{n}\end{array}$ & $\begin{array}{c}-20.0^{* *} \\
5.0 \\
8\end{array}$ & $\begin{array}{c}-24.1^{*} \\
6.5 \\
7\end{array}$ & $\begin{array}{c}+9.5^{\dagger} \\
8.9 \\
8\end{array}$ & $\begin{array}{c}+12.9 \dagger \\
9.5 \\
8\end{array}$ \\
\hline R-Cerebellum & $\begin{array}{l}\mathrm{m} \\
\mathrm{SE} \\
\mathrm{n}\end{array}$ & $\begin{array}{c}57.6 \\
6.3 \\
8\end{array}$ & $\begin{array}{c}\% \text { Change in } \mathrm{CBF}(\%) \\
\mathrm{m} \\
\mathrm{SE} \\
\mathrm{n}\end{array}$ & $\begin{array}{c}-21.4^{* * *} \\
1.8 \\
8\end{array}$ & $\begin{array}{c}-22.2^{* * *} \\
2.9 \\
8\end{array}$ & $\begin{array}{c}+4.4^{* *} \\
8.3 \\
8\end{array}$ & $\begin{array}{c}+11.4^{\dagger} \\
11.8 \\
6\end{array}$ \\
\hline $\begin{array}{l}\text { L-Hemisphere } \\
\quad \text { (pariet.) }\end{array}$ & $\begin{array}{l}\mathrm{m} \\
\mathrm{SE} \\
\mathrm{n}\end{array}$ & $\begin{array}{c}50.2 \\
16.0 \\
6\end{array}$ & $\begin{array}{c}\% \text { Change in } \mathrm{CBF}(\%) \\
\mathrm{m} \\
\mathrm{SE} \\
\mathrm{n}\end{array}$ & $\begin{array}{c}-33.5^{*} \\
7.0 \\
6\end{array}$ & $\begin{array}{c}-28.0^{*} \\
6.1 \\
4\end{array}$ & $\begin{array}{c}+0.4 \\
13.3 \\
6\end{array}$ & $\begin{array}{c}+13.8 \\
23.4 \\
5\end{array}$ \\
\hline $\begin{array}{c}\text { Initial MA } \\
\quad \begin{array}{l}\mathrm{m} \\
\mathrm{SE} \\
\mathrm{n}\end{array}\end{array}$ & $\begin{array}{l}\mathrm{P}(\mathrm{mm} \\
92.1 \\
9.6 \\
8\end{array}$ & & $\begin{aligned} & \triangle \mathrm{MABP}(\mathrm{mmHg}) \\
& \mathrm{m} \\
& \mathrm{SE} \\
& \mathrm{n}\end{aligned}$ & $\begin{array}{c}+2.6 \\
3.7 \\
8\end{array}$ & $\begin{array}{l}0 \\
4.8 \\
8\end{array}$ & $\begin{array}{r}-7.0 \\
7.5 \\
8\end{array}$ & $\begin{array}{c}-9.1 \\
9.3 \\
7\end{array}$ \\
\hline
\end{tabular}

\section{考案}

今回の 新鮮自家血注入実験は，いわゆる早期血管挛

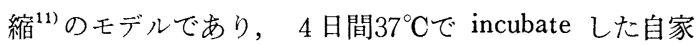
血・髄液混合液注入実験は晚期血管挛縮 ${ }^{11)}$ のモデルとい える、その何れの実験モデルに拈いても, 大槽内注入直 後, 注入液がまだ脳表に到達していない早期に, 既に脳 表で著しい血管孪縮が生じていた。この事は, 両実験に 打ける血管挛縮の発現が, 注入液由来の血管作動性物質 の血管平滑筋に対する直接作用によるものでなく, むし ろ神経性因子の関与の可能性を示唆するものといえる.

脳血管への神経分布については，1664年に Willis が 始めて記載して以来，19世紀から20世紀初頭に鍍銀染色 法などにより $10 \mu$ 前後の動脈にまで密なる神経支配の存 在する事が証明されている ${ }^{4)}$.

一方, クモ膜下出血の際には, 異常発汗, 高体温, 血 圧動摇, 瞳孔異常, 心電図異常 ${ }^{12)}$ がしばしば認められ, 以前より自律神経異常の存在が推察されていたが, 最 近自律神経機能検査 ${ }^{13)}$, 血清 dopamine- $\beta$-hydroxylase
(DBH) 活性 ${ }^{6)}{ }^{14)}$, 血清 noradrenaline, adrenaline の異常 值 $^{5)^{7)}}$ より，ノルアドレナリン作動性神経系の活動え進 が実際に生じている事が確められている.更にこれら血 清 catecholamine 值は脳血管孪縮が著しい症例 ほど高 $\left\langle{ }^{7)}\right.$, 血清 $\mathrm{DBH}$ 活性の脳静動脈較差も血管孪縮 の認

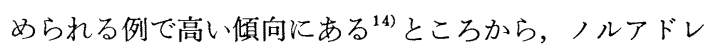
ナリン作動性神経系が血管孪縮にかなり関与している事 が臨床的に疑われて来た。

事実, 動物実験では頝部交感神経の刺激で脳軟膜血管 に収縮の生ずる事が確められている4). しかも近年, 組 織化学的 ${ }^{15)}$ に或いは電顕的検索 ${ }^{16)} に よ り$ 脳血管にはノル アドレナリン作動性神経が豊富に分布している事が証明 され, 更にその由来は脳軟膜血管は頝部交感神経由来で あるが，脳実質内血管については青斑核由来の central noradrenergic system の支配を受けていると考えられる 様になって来た ${ }^{17) 18)}$.

今回用いたフサリン酸 (5-butylpicolinic acid) は, dopamine- $\beta$-hydroxylase $(\mathrm{DBH})^{8)}$ を特異的に阻害し, 
血管壁, 脳を含め生体内各部位での noradrenaline 含量 を有意に低下させる事が知られている ${ }^{919)}$. 新鮮自家血 注入実験および incubate した自家血・䯣液混合液注入 実験に敃いて，注入後持続して認められた血管挛縮に対 し，フサリン酸が有意な挛縮寛解作用をみせた事は，血 管挛縮にノルアドレナリン作動性神経終末よりの noradrenaline の放出充進が関与している事を示している.

但し，ここで問題となるのは, フサリン酸の血管壁に 対する直接作用の可能性である ${ }^{20) 21)}$. その論拠として投 与直後の血圧下降が生体内 noradrenaline の減少と時間 的に一致しない事が挙げられている20121). しかし神経終 末より刺激により放出され得る noradrenaline は, 速い turn overで新しく合成されつつある small storage pool 内の noradrenaline であるとされており, その量は神経 終末の 総貯蔵量の 僅か2 $3 \%$ に過ぎない ${ }^{22)}$. 従ってフ サリン酸投与直後より，この small storage pool 内の noradrenaline 合成阻害により総貯蔵量の有意の減少を 来たす以前に, ノルアドレナリン作動性神経興奮の伝達 阻害が生じている可能性は充分に考えられる.またフサ リン酸投与後 5〜20分に打いて 血管挛縮寛解の進展が緩 徐になり，下降した血圧が一度回復する過程は，ノル アドレナリン作動性神経終末で枯渴した small storage pool 内の noradrenaline が, 直接放出はされない turn over の遅い large storage pool 内の noradrenaline ${ }^{22)} に$ より補充された事による可能性が考えられる. 新鮮血注 入実験, 自家血・䯣液混合液注入実験の何れに拈いて も，フサリン酸投与後30分以降より挛縮寛解が一層著明 となり，血圧も緩徐な再下降を示した。これは血管壁内 の $\mathrm{DBH}$ 阻害が投与後30分に扣いて最大となったとする 報告 ${ }^{19)}$ と一致している. 従って少なくともこの時点以降 の孪縮寛解の進展についてはノルアドレナリン作動性神 経阻害が主因である事に異論はないと考えられる。

以前からノルアドレナリン作動性神経 $\alpha$ 受容体遮断 剂の phenoxybenzamine や phentolamine が血管挛縮に 対し試みられて来たが，その効果は必しも明らかでな く, この点から血管孪縮におけるノルアドレナリン作動 性神経因子の関与を否定する意見もある ${ }^{23)}$. しかし脳 血管には特異な血液脳関門があり，静注で無効であるが クモ膜下腔に局所的に投与した際は有効との報告 ${ }^{23)}$ む るので, 受容体遮断剤を静注あるいは動注した実験結果 の評価については慎重にすべきである。 それに対しフサ リン酸は血液脳関門を通過するとされ 24), 静注後直ちに 脳血管壁ノルアドレナリン作動性神経終末に取込まれて
作用するものと考えられる。 また上記受容体遮断剂は presynaptic adrenoceptor ( $\alpha_{2}$ receptor) を介して逆に神 経終末よりの noradrenaline の放出を促進する事が知ら れており ${ }^{22)}$, その点からも今までの報告を再検討する必 要があろう。

更に現在までの多くの血管孪縮の実験報告では脳底動 脈がモデルに用いられている ${ }^{2)}$. しかし脳底動脈の血管 孪縮は内頝動脈系（前大脳動脈および中大脳動脈領域） に比べ臨床的にかなりまれであるし1，，ルアドレナリ ソ作動性神経の分布も脳底動脈は内頝動脈系に比べかな り粗であるとされている年，これらの点で脳底動脈を用 いた実験より血管孪縮におけるノルアドレナリン作動性 神経因子の関与につき否定的な報告についてはその解釈 に注意すべきと思われる。

今回の実験結果につきもう一つ問題となるのは理論的 に DBH 阻害の結果, 神経終末での dopamine の増加 の可能性が考えられる. 更に dopamine には交感神経 節細胞体およびノルアドレナリン作動性神経終末の受容 体を介してノルアドレナリン作動性神経興奮伝達を阻害 する作用のある事が知られている ${ }^{25)}$.しかし実際には, フサリン酸投与後 dopamine は monoamine oxidase に よる分解を受け殆ど増加しないとされている年24). また 少量の dopamine は逆に脳血流減少に働くとされてい $る^{26)}$. 従って今回得られたフサリン酸の効果について は, dopamine を介する間接的な作用の関与を考慮する 必要はないであろう。

今回測定した脳血流量は，大槽内注入 10 分後で，小 脳，大脳各部位一様に有意な減少を示した。この原因と して, まず脳軟膜動脈の血管孪縮によって, 脳実質の灌 流圧が autoregulation ${ }^{27)}$ の下限以下まで下ったか, 或 いは下限以上でも SAH 後の autoregulation の障害 ${ }^{28)}$ に より灌流圧依存性に血流が減少した可能性が考えられ る. 更に血流量減少が両側大脳半球および小脳半球で一 様に認められた事から， central noradrenergic system ${ }^{17)}$ 18）を介乙て脳実質内血管自身も血管挛縮を生じた可能 性も考慮すべきであろら. 事実, 文献上, 青斑核刺激で 大脳半球の血流量減少を来たしたとの報告 ${ }^{18)}$ みられ る.

incubate した自家血・髄液混合液注入実験と新鮮血注 入実験の 結果を比較すると, 前者の方が血管孪縮が強 く，また注入後血圧もやや上昇した。この事は混合液中 に，4日間 incubate の間に新鮮血自身よりも強い， ， ルアドレナリン作動性神経刺激物質の生じた可能性を示 
唆している. Endo \& Suzuki は同様に incubate した混 合液に血管壁ノルアドレナリン作動性神経終末の small cored vesicle を消失させる作用がある事を報告してお $り^{29)}$ ，上述の結果と考えあわせ興味深いまたこの種の 混合液中に検出される oxyhemoglobin が血管挛縮の原 因物質であるとする報告が多いが2)，それがノルアドレ ナリン作動性神経終末を刺激して作用を及ぼすかいなか は今後の検討を待たねばならないであろう。また新鮮血 自身にも脳血管壁神経終末の noradrenaline 蛍光を著明 に消失させる事が報告されている ${ }^{30)}$. 以上の如く, クモ 膜下腔に血液成分の混入する事は, 程度の差こそあれ, ノルアドレナリン作動性神経終末に刺激を与える事が電 顕的 ${ }^{29)}$ または組織化学的 ${ }^{30)}$ に明らかとされており, こ れらの事実は今回のフサリン酸の効果を裏付けるものと 考えられる.

今回は急性実験のため, クモ膜下出血後 3〜5 日後よ り明らかとなる denervation hypersensitivity ${ }^{6)}$ やその他 生体内で生ずる変化の血管孪縮への関与については検討 出来なかった．これらの問題については, 臨床的に我々 のみる血管孪縮に近いモデルとして行なった慢性実験に おいて別に検討する予定である。

稿を終るに臨み, 終始御指導および御校閲頂いた後藤 文男教授に深謝すると共に, 本研究に御協力頂いた村松 文雄講師, 福内靖男講師, 岩垣皓之学士, 天野隆弘博 士，岡安裕之博士に感謝の意を表します。

なお, 本論文の要旨は第 2 回日本脳卒中学会総会 $(1977$ 年 2 月, 福岡) にて発表した。

本研究費の一部は文部省昭和53年度科学研究費補助金 （248211）および厚生省特定疾患脳脊䯣血管異常調査研 究班の研究費によつた。

\section{文献}

1) 斎藤 勇 : クモ膜下出血時に打ける脳血管孪縮 一その臨床面について一，脳神経29:369,1977

2) 福内靖男, 田中耕太郎, 後藤文男 : 脳血管挛縮 の病態生理一脳血管孪縮物質一, 循環器科 3 : 43, 1978

3) 太田富雄, 梶川 博, 吉川幸弘 : 脳血管挛縮の 治療, 循環器科 $3: 56,1978$

4) 後藤文男 : 脳循環 の神経性調節, 脳卒中 1 : 303, 1979

5) Benedict CR, Loach AB: Sympathetic nervous system activity in patients with subarachnoid homorrhage, Stroke 9: 237, 1978

6) Kendallharden $T$, Klein RL, Smith RR, et al: Serum dopamine $\beta$-hydroxylase activity following subarachnoid hemorrhage in man, Med Biol 53: 100, 1975

7) Peerless SJ, Griffiths JC: Plasma catecholamines following subarachnoid hemorrhage, In Smith RR, Robertson JT ed "Subarachnoid hemorrhage and cerebrovascular spasm", Springfield, Charles C Thomas Pub, 1975, p 148

8) Kaufman S, Friedman S: Dopamine- $\beta$-hydroxylase, Pharmacol Rev 17: 71, 1965

9) Nagatsu $T$, Hidaka $H$, Kuzuya $H$ et al: Inhibition of dopamine $\beta$-hydroxylase by fusaric acid (5-butylpicolinic acid) in vitro and in vivo, Biochem Pharmacol 19: 35, 1970

10) Doyle TF, Martins AN, Kobrine AI: Estimating total cerebral blood flow from the initial slope of hydrogen washout curves, Stroke 6: 149, 1975

11) Brawley BW, Strandnes DE Jr, Kelly WA: The biphasic response of cerebral vasospasm in experimental subarchnoid hemorrhage, $\mathrm{J}$ Neurosurg 28: 1, 1968

12) Weintraub BM, McHenry LC Jr: Cardiac abnormalities in subarachnoid hemorrhage: A resumé, Stroke 5: 384, 1974

13）島津邦男, 後藤文男, 小松本悟 : 脳血管障害と 自律神経機能, 自律神経 $15: 193,1978$

11) 後藤文男, 神田 直, 山本正博 5 : くも膜下出 血急性期の 血清 dopamine- $\beta$-hydroxylase 活性 について (第 2 報), 厚生省特定疾患脳脊髄血 管異常調査研究班昭和50年度研究報告書 (昭和 51 年 3 月) p. 66

15) Nielsen KC, Owman C: Adrenergic innervation of pial arteries related to the circle of Willis in the cat, Brain Res 6: 773, 1967

16) Dahl E, Nelson E: Electron microscopic observations on human intracranial arteries. II . Innervation, Arch Neurol 10: 158, 1964

17) Hartman BK, Zide D, Udenfriend S: The use of dopamine $\beta$-hydroxylase as a maker for the 
central noradrenergic nervous system in rat brain, Proc Natl Acad Sci USA 69: 2722, 1972

18) Raichle ME, Hartman BK, Eichling JO et al: Central noradrenergic regulation of cerebral blood flow and vascular permeability, Proc Natl Acad Sci USA 72: 3726, 1975

19) Hidaka H, Shoka F, Hashizume $Y$ et al: Inhibition of dopamine $\beta$-hydroxylase in blood vessels by picolinic acid derivatives in vivo and their antihypertensive effects, Japan J Pharmacol 25: 515, 1975

20）日高弘義, 原ふみ子, 原田伸雄ら：ドーパミン $\beta$-水酸化酵素の in vivo 阻害と血圧の変化, 日 薬誌 $70: 102 \mathrm{p}, 1974$

21) Hidaka $H$, Asano $M$ : Relaxation of isolated rabbit arteries by fusaric (5-butylpicolinic) acid, J Pharmacol Exp Ther 199: 620, 1976

22) Burnstock G, Costa M: Adrenergic neurons. Their organization, function and development in the peripheral nervous system. London, Chapman and Hall Ltd, 1975

23) 半田譲二, 小山素麿, 米田俊一ら : 実験的脳動 脈孪縮に対する Phenoxybenzamine の効果, 脳 神経外科 $3: 577,1975$

24) Hidaka $\mathrm{H}$, Hara F, Harada $\mathrm{N}$ et al: Selective inhibition of dopamine- $\beta$-hydroxylase in the peripheral tissues by 5-dimethyldithiocarbamylpicolinic acid; Its effect on stress-induced ulcer, ethanol-induced sleep and blood pressure, J Pharmacol Exp Ther 191: 384, 1974

25) Westfall TC: Local regulation of adrenergic neurotransmission, Physiol Rev 57: 659, 1977

26) von Essen C: Effects of dopamine on the cerebral blood flow in the dog, Acta Neurol Scand 50: 39, 1974

27) 後藤文男 : 脳循環 の Autogeulation, 呼吸之循 環 $14: 569,1966$

28) Hashi K, Meyer JS, Shinmaru S et al: Changes in cerebral vasomotor reactivity to $\mathrm{CO}_{2}$ and autoregulation following experimental subarachnoid hemorrhage, J Neurol Sci 17: 15, 1972

29) Endo S, Suzuki J: Experimental cerebral vasospasm after subarachnoid hemorrhage. Participation of adrenergic nerves in cerebral vessel wall, Stroke 10: 703, 1979

30) Peerless SJ, Kendall MJ: The innervation of the cerebral blood vessels, In Smith RR, Robertson JT ed "Subarachnoid hemorrhage and cerebrovascular spasm", Springfield, Charles C Thomas Pub, 1975, p 38 


\title{
Abstract \\ Role of noradrenergic system in cerebral arterial vasospasm after subarachnoid hemorrhage \\ 1. Acute experiment
}

\author{
Kortaro Tanaka, M.D. \\ Department of Neurology, School of Medicine, Keio University
}

The pathophysiology of cerebral arterial spasms after subarachnoid hemorrhage (SAH) are not well known yet. This study was designed to clarify the role of noradrenergic system in the spasm.

Effects of fusaric acid (F.A.), a potent inhibitor of dopamine- $\beta$-hydroxylase, on pial arterial diameter and regional cerebral blood flow ( $\mathrm{r}-\mathrm{CBF}$ ) were investigated in 16 cats with pial arterial spasm after experimental SAH. Cats were anesthetized with $\alpha$-chloralose $(50 \mathrm{mg} / \mathrm{kg})$ and urethane $(500 \mathrm{mg} / \mathrm{kg})$. After the administration of alcuronium chloride, respiration was maintained constant throughout the experiment. Parietal craniectomy was performed for the microphotographic observation of pial vessels. r-CBF were measured by the hydrogen clearance method in four regions of the brain. Vasospasms were induced by the cisternal injection of the fresh autogenous blood (group 1 (8 cats)) or the mixture of autogenous blood and CSF incubated for 4 days (group 2 (8 cats) ). F.A. $(50 \mathrm{mg} / \mathrm{kg}$ ) was administered intravenously 45 to 50 minutes after the cisternal injection.

The following results were obtained.

1) In both groups, the diameters of pial arteries began to decrease significantly $(p<0.001-0.005)$ immediately after the cisternal injection. These arterial spasms continued up to the time of administration of F.A. r-CBF showed a reduction almost in parallel with the decrease of pial arterial diameters in all regions. The degree of vasospasm and $\mathrm{r}-\mathrm{CBF}$ reduction in group 2 were more marked than those in group 1.

2) Intravenous injection of F.A. resulted in a complete disappearance of the spasm $(p<0.001)$ and the $\mathrm{r}$-CBF rapidly restored and even exceeded the control level in spite of a moderate fall of blood pressure. In either group maximum effects of the drug were observed 40 minutes after the administration of the agent.

The above data suggest the participation of the activity of noradrenergic nerve endings in the pathogenesis of cerebral arterial spasm after SAH.

(Jpn. J. Stroke 2: 269-279, 1980) 